\title{
How can water quality be improved when the urban waste water directive has been fulfilled? A case study of the Lot river (France)
}

\author{
Josette Garnier ${ }^{1} \cdot$ Antsiva Ramarson $^{1} \cdot$ Vincent Thieu $^{1} \cdot$ Julien Némery $^{2} \cdot$ Sylvain Théry $^{3} \cdot$ Gilles Billen $^{1}$. \\ Alexandra Coynel ${ }^{4}$
}

\begin{abstract}
The Lot river, a major tributary of the downstream Garonne river, the largest river on the Northern side of the Pyrenees Mountains, was intensively studied in the 1970s. A pioneering program called "Lot Rivière Claire" provided a diagnosis of water quality at the scale of the whole watershed and proposed an ambitious program to manage nutrient pollution and eutrophication largely caused by urban wastewater releases. Later on, the implementation of European directives from 1991 to 2000 resulted in the nearly complete treatment of point sources of pollution in spite of a doubling of the basin's population. At the outlet of the Lot river, ammonium and phosphate contamination which respectively peaked to $1 \mathrm{mg} \mathrm{N}-\mathrm{NH}_{4} \mathrm{~L}^{-1}$ and $0.3 \mathrm{mg} \mathrm{P}-\mathrm{PO}_{4} \mathrm{~L}^{-1}$ in the $1980 \mathrm{~s}$ returned to much lower levels in recent years $\left(0.06 \mathrm{mg} \mathrm{N}-\mathrm{NH}_{4} \mathrm{~L}^{-1}\right.$ and $0.02 \mathrm{mg} \mathrm{P}_{-} \mathrm{PO}_{4} \mathrm{~L}^{-1}$ ), a reduction by a factor 15 . However, during this time, nitrate contamination has regularly

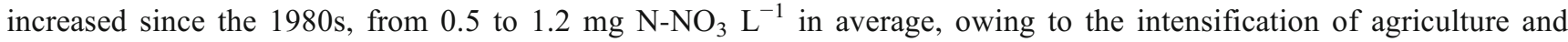
livestock farming. Application of the Riverstrahler model allowed us to simulate the water quality of the Lot drainage network for the 2002-2014 period. We showed that, with respect to algal requirements, phosphorus and silica are well balanced, but nitrogen remains largely in excess over phosphorus and silica. This imbalance can be problematic for the ecological status of the water bodies. Using the model, for simulating various scenarios of watershed management, we showed that improvement of urban wastewater treatment would not result in any significant change in the river's water quality. Even though arable land occupies a rather limited fraction of the watershed area, only the adoption of better farming practices or more radical changes in the agro-food system could reverse the trend of increasing nitrate contamination.
\end{abstract}

Keywords Nutrient fluxes $\cdot$ River water quality $\cdot$ Biogeochemical modeling $\cdot$ Lot river

Responsible editor: Philippe Garrigues

Josette Garnier

josette.garnier@upmc.fr

1 UMR 7619 Metis (Sorbonne Université - CNRS - EPHE) BP 123, Tour 56-55, Etage 4, 4 Place Jussieu, 75005 Paris, France

2 Université Grenoble Alpes, CNRS, IRD, Grenoble INP (Institute of Engineering Univ. Grenoble Alpes), IGE, F-38000 Grenoble, France

3 CNRS FR-3020 FIRE, BP 123, Tour 56-55, Etage 4, 4 Place Jussieu, 75005 Paris, France

4 Université de Bordeaux, UMR 5805 EPOC-OASU—allée Geoffroy Saint-Hilaire, 33615 Pessac, France

\section{Introduction}

One of the major water policy tools in Europe, the Urban Waste Water Treatment Directive (UWWTD 1991, Council Directive 91/271/EEC), was adopted on 21 May 1991 to protect the quality of water subject to oxygen depletion, nutrient pollution, and eutrophication from the adverse effects of urban and industrial wastewater discharges. The Directive requires an appropriate collection of sewage and regulates discharges of wastewater by specifying the minimum type of treatment to be provided and setting maximum emission limits of the major pollutants (organic load and nutrients). Later, the Water Framework Directive (WFD 2000) was dedicated to providing coherence to legislation with EU policies in the domain of 
water, and the watershed scale was adopted as a management scale with the aim of achieving good ecological status of water masses in 2015. These two directives already considerably contributed to improving water quality, most particularly by reducing organic carbon (hence improving oxygenation) and phosphorus (Passy et al. 2013; Romero et al. 2013, 2016).

The Lot river is a major tributary of the downstream Garonne river, the largest river on the northern side of the Pyrenees Mountains, which forms the Gironde Estuary with the Dordogne river. The Lot river, draining an area of $11,686 \mathrm{~km}^{2}$, has its source in the Massif Central (Mont Lozère, at $1295 \mathrm{~m}$ elevation). The construction of reservoirs in the upstream watershed, beginning in the 1930s, reached a current water storage capacity of $560 \mathrm{Mm}^{3}$, with often uncoordinated regulation of water uptake and release, which seriously perturbed the hydrological regime (Maneux et al. 2001). Another major problem of the Lot river is its historical polymetallic contamination, notably in a small catchment (the Riou Mort river), due to former mining and oretreatment activities (e.g., Audry et al. 2004a,b; Coynel et al. 2009). The downstream catchment of the Riou-Mort $\left(150 \mathrm{~km}^{2}\right.$; mean monthly water discharges, $\sim 0.3$ to $3 \mathrm{~m}^{3} / \mathrm{s}$ ) drains former coal mining and waste disposal (mostly industrial waste from the now-abandoned zinc ore treatment) from the Société des Mines et Fonderies de Zinc de la VieilleMontagne mining company, founded in 1837, which in 2001 evolved into Umicore, a global materials technology and recycling group.

Already two decades before the Waste Water Treatment Directive, in 1969, a pioneering program (Lot Rivière Claire), dedicated to the integrated protection of the river, was launched on the Lot river by a French association for the development of the Lot Valley (Association pour l'Aménagement de la Vallée du Lot) with two main objectives: to develop a better understanding of the ecology of the river and to promote the economic and environmental development of the Lot Valley.

At that time, better sharing of the water resources became necessary (Décamps 1978), because of increasing water use for hydropower and rising water requirement for drinking water, industry, agriculture, and tourism. The development plan of the area was designed through the dialog with all concerned of French administrative institutions (five departments and four regions) that were willing to adopt an integrative spatial approach to satisfy the needs of these multiple uses.

The resulting program for land development in 1989 provided coordinated management of water release during low summer water beneficial for other economic activities and the ecological state of the river. Decantation systems were installed as soon as 1975 by the mining industries to reduced suspended solid and associated contaminants, and more efficient measures were taken to control the situation (remediation of polluted soils), significantly reducing contamination
(Lapaquellerie et al. 1995; Blanc et al. 1999; Audry et al. 2004a,b; Coynel et al. 2007; Morin et al. 2008; Shinn et al. 2009; Arini et al. 2011).

Besides the agreement found for regulating water fluxes and decreasing the pollution resulting from mining industries, considerable efforts were dedicated to reducing the nutrient and organic matter released from domestic wastewater and agro-food industries.

Décamps (1978) evaluated the point sources of urban wastewater at 232,000 inhabitant equivalents (inh. eq.) plus 96,000 inh. eq. from industrial releases. He projected that the total wastewater collection could reach 560,000 inh. eq. by the mid-1980s. An ambitious program of wastewater treatment was launched, anticipating the obligations later stipulated by the European Urban Waste Water Directive (UWWD 1991) and the later Water Framework Directive (WFD 2000). The success of these measures was manifest, particularly in terms of ammonium and phosphate contamination.

Although low flow in summer can favor algal development to a level typical for meso-eutrophic systems, phytoplankton composition was dominated by diatoms and Chlorophyceae, and only a small proportion of harmful algae, such as Cyanobacteria, was found (Capblancq and Dauta 1978). Despite that eutrophication has not been yet an important environmental problem in the Lot, it remains a threat in dry summer when many river reaches tend toward functioning as stagnant systems characterized by water column stratification (Capblancq and Toureng 1978), leading to harmful algal biomass as was observed in the Tarn river, another major tributary of the Garonne river (Bertrand et al. 2004). This type of toxic algae events have indeed killed several dogs in 2011 (http://www.europe1.fr/france/des-algues-toxiques-dans-letarn-656657), and alerts are regularly published in local or national news papers (http://www.leparisien.fr/societe/ attention-aux-algues-tueuses-de-chiens-24-08-20177209819.php; http://www.larep.fr/orleans/environnement/ 2017/08/23/cyanobacteries-1-ars-rappelle-les-mesures-deprevention_12524110.html).

The aim of the present study was to revisit the ecological functioning of the Lot river related to nutrients and subsequent possible eutrophication or toxic algal development after the wastewater treatment programs had been completed. Indeed, although wastewater plants have greatly improved their treatments in European countries, decreasing phosphorus and nitrogen load (in France: Passy et al. 2013; Romero et al. 2013; Romero et al. 2016; Minaudo et al. 2015; in other EU countries: Ulen et al. 2007; Bouraoui and Grizzetti 2011), nitrate contamination due to intensive agriculture has increased in the past four decades, or at best has plateaued. Although agricultural measures have been applied to reduce the use of industrial fertilizers, by introducing good agricultural practices (split application of fertilizers, preventing leaching of bared winter soils by introducing catch crops, etc.), in most cases, 
these measures have failed to effectively reduce nitrate contamination (Davis et al. 2012; Volk et al. 2009; Garnier et al. 2014).

As a synthetizing tool in this endeavor, we implemented the Riverstrahler model, an ecological model of drainage network (Billen et al. 1994; Garnier et al. 1995, 2002), embedded into a GIS-Seneque environment (Ruelland et al. 2007), which, once validated, allows exploring scenarios of alternative water quality management. Differently from previous modeling approaches developed for the main branch of the Lot (Capblancq et al. 1982; Thébaut and Quotbi 1999), the Seneque-Riverstrahler model operates at the scale of the whole watershed and takes other ecological compartments than phytoplankton explicitly into account.

\section{Material and methods}

\section{Study site}

The Lot river watershed, located in southwestern France, covers a surface area of $11,686 \mathrm{~km}^{2}$ (Fig. 1) for a mean annual water discharge of $\sim 150 \mathrm{~m}^{3} / \mathrm{s}$. Tributary of the Garonne river $\left(55,000 \mathrm{~km}^{2}\right)$ on its right bank, it is divided into three main geological zones: (i) igneous (basalts and granites) and metamorphic (micaschists and gneisses) rocks in the upstream watershed, (ii) Jurassic calcareous sedimentary rocks in the median watershed, and (iii) Tertiary and Quaternary alluvium deposits in the downstream watershed (Audry et al. 2010). The upstream basin is drained by two major tributaries, the Truyère and the upstream Lot, accounting for $47 \%$ of the total surface area (Fig. 1a) and 38\% of the discharge at the downstream station, Temple-sur-Lot (km 305), close to Villeneuvesur-Lot (Capblancq and Tourenq, 1978), about $20 \mathrm{~km}$ upstream of the confluence with the Garonne river, at $22 \mathrm{~m}$ altitude.

Being mostly under the influence of the Atlantic, it is also impacted by Mediterranean and mountainous conditions, leading to a complex hydrological regime (Toureng et al. 1978). Reservoirs are mainly located on the Truyère river (538 out of $560 \mathrm{Mm}^{3}$ ) and were impounded from 1933 to 1962 by Electricite de France (EDF), with uncoordinated management until 1989. Of the nine reservoirs of the Truyère, the Grandval and Sarrans Reservoirs account for the largest proportion of the total water stored.

The population of the Lot river currently totals 472,274 inhabitants (INSEE, 2013) (population density, 40.4 inhab. $\mathrm{km}^{-2}$ ), $16 \%$ concentrated in the major cities (Fig. 1b). Among the 348 wastewater treatment plants (WWTPs) located within the basin, 11 treat loads greater than 10,000 inhabitant equivalents $(69 \%$ of the total amount of pollution emitted) and 20 WWTPs above 2000 inh. eq., together totaling $90 \%$ of the total inh. eq.
Besides an activated sludge biological treatment, these 33 WWTPs treat $71 \%$ of the inh. eq. with nitrification and denitrification and $62 \%$ with an additional chemical dephosphatation.

Land use (Fig. 1c) is distributed into forest (45\%) and grassland (47\%). Arable land (6\%) is dominated by intensive cropping system with short 3-year rotation, alternating soft wheat, maize (often irrigated), and fertilized artificial grassland. Vineyards (Cahors wine) are also important agricultural activities together with market gardening (plums, apples, melons, kiwis, etc.) and duck keeping.

\section{The Riverstrahler approach}

The Riverstrahler modeling approach was applied to the Lot river (2002-2014) using existing data (Table 1) and original data and measurements obtained in the scope of the ANRTwin Rivers project (Coynel et al. 2016).

Riverstrahler is a process-based model of nutrient transfer and biogeochemical functioning of large river systems (Billen et al. 1994; Garnier et al. 1995; Billen and Garnier 2000; Garnier et al. 2002) at a seasonal scale. It is a biogeochemical tool, describing in detail the instream processes affecting nutrients and aquatic microbial life and related water quality in a drainage network as constrained by the geomorphology of the basin, its hydrology, climate (light, temperature), and human activities (described in terms of point and diffuse sources). The originality of the modeling approach lies in the coupling of a representation of the whole drainage network, partly based on Strahler's (1957) stream order classification by sub-basins, and a detailed (kilometric) representation of the main river branches. Nine sub-basins have been taken into account, the largest being the Truyère, the upstream Lot, and the Célé $\left(3283,2244\right.$, and $1367 \mathrm{~km}^{2}$, respectively). The main branch of the Lot, from the confluence of the Truyère, is $310 \mathrm{~km}$ long and has a direct watershed of $3135 \mathrm{~km}^{2}$. This geomorphological representation for which the hydrology is generated (see below) is coupled with a biogeochemical process model (RIVE). The RIVE model takes into account the dynamics of three algal groups (diatom, green algae, and cyanobacteria) and two groups of zooplankton (cladocerans and rotifers) to calculate their biomass and simulates the biogeochemical cycles of carbon, oxygen, nitrogen, phosphorus, and silica in the drainage network, also taking heterotrophic and nitrifying bacterial communities explicitly into account (see Garnier et al. 2002). All these processes important in the transformation, elimination, and/or immobilization of nutrients during their in-stream transfer are calculated at the seasonal scale (at a 10-day resolution). A full description of the RIVE model is available at www.fire.upmc.fr/rive 


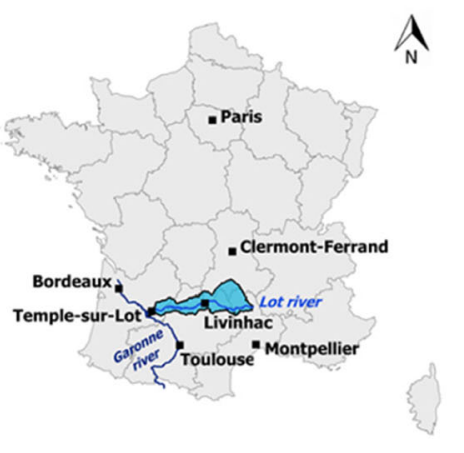

0100200 kilometers

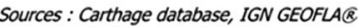
UMR METIS 7619 - MaV 2015 a

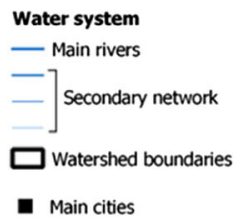

Treatment capacity of WWTP (population equivalent)

- $10000-50000$

$1000-10000$

- $100 \cdot 1000$

$10-100$

b
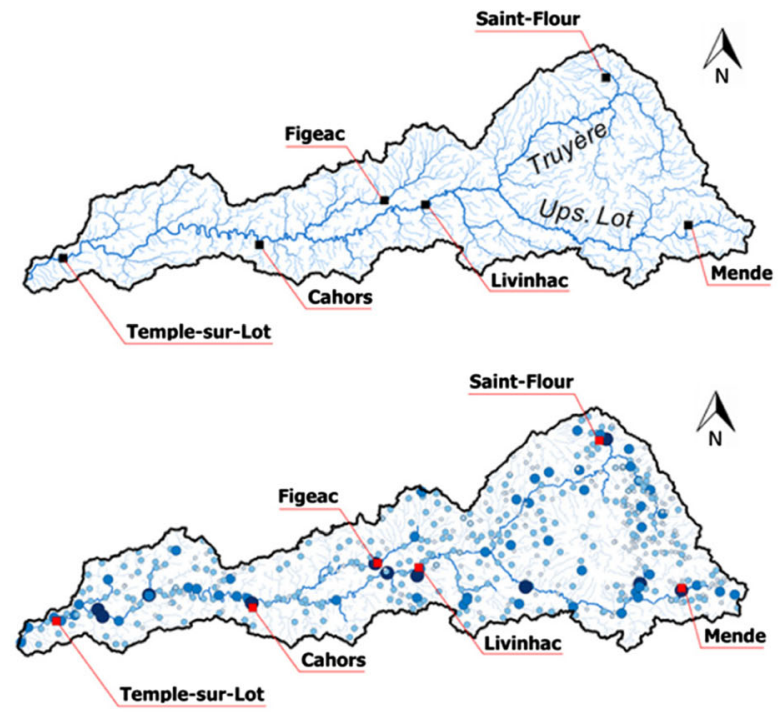

- Main rivers

Secondary network

$\square$ Watershed boundaries

- Main cities

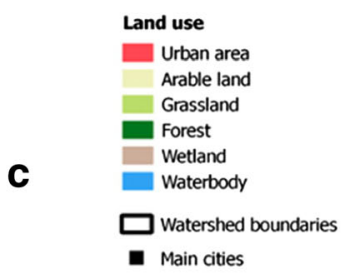

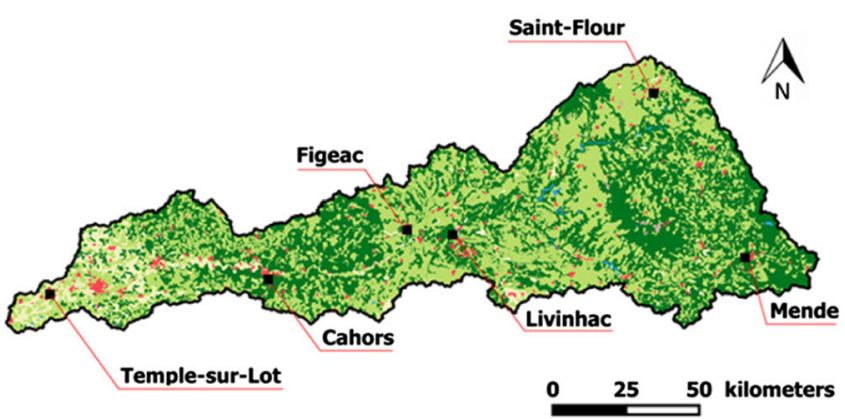

Sources : AESN, Carthage database, IGN GEOFLA@ UMR METIS 7619 - MaY 2015

Fig. 1 a Situation of the Lot river basin and its drainage network. b Treatment capacity of wastewater treatment plants of the Lot basin, as an indicator of population density. $\mathbf{c}$ land use map

\section{The Riverstrahler model inputs}

Morphology and hydrology The hydrographic network GIS layer is derived from the CarTHAgE® database, combined with DEM data from NASA/SRTM (Jarvis et al. 2008) to delineate elementary watersheds. Hydrological data are those provided by the HYDRO database (Leleu et al. 2014), averaged at a daily time step and then broken down into surface runoff and base flows, using the Eckhardt recursive filter (Eckhardt 2008), in order to make possible distinguishing nutrient inputs from these two components of the discharge. Reconstruction of hydrological regimes used 27 gauging stations for the 2002-2012 period and then 18 stations for 20132014. Specific surface and base flows were thus generated for each sub-basin and branch considered for the modeling project (here nine sub-basins and one main branch). From mid2008 to 2014, the discharge at Livinhac was reconstructed from two other gauging stations (Fig. 2, see details in the legend). The presence of reservoirs in the upstream basin, which does not strongly affect the hydrological behavior of the downstream river (Tourenq et al., 1978), was implicitly taken into account based on observed discharge measurements.

Point and diffuse sources Point sources are calculated in terms of nitrogen, phosphorus, carbon, and suspended solid fluxes on the basis of a spatial census of wastewater treatment plant releases (see Fig. 1b) with associated treatment capacity and treatment type. They also include the inventory of industrial releases in the basin (data sources in Table 1). Diffuse sources are estimated as nutrient concentrations characterizing each of the watershed's land use classes (Corine Land Cover database: Bossard et al. 2000; EEA 2007) and multiplied by surface runoff and base flow. Most of the data are retrieved from European databases (see Table 1) and regionalized for each land use class within each statistical NUTS region (NUTS level 3). Diffuse sources of suspended solids are derived from PESERA estimates of soil erosion (Kirkby et al. 2004) and combined with topsoil data from the European LUCAS survey (Thoth et al. 2013) to estimate land-based emissions of particulate phosphorus and organic carbon. Dissolved silica concentrations are assigned according to litho-morphological 


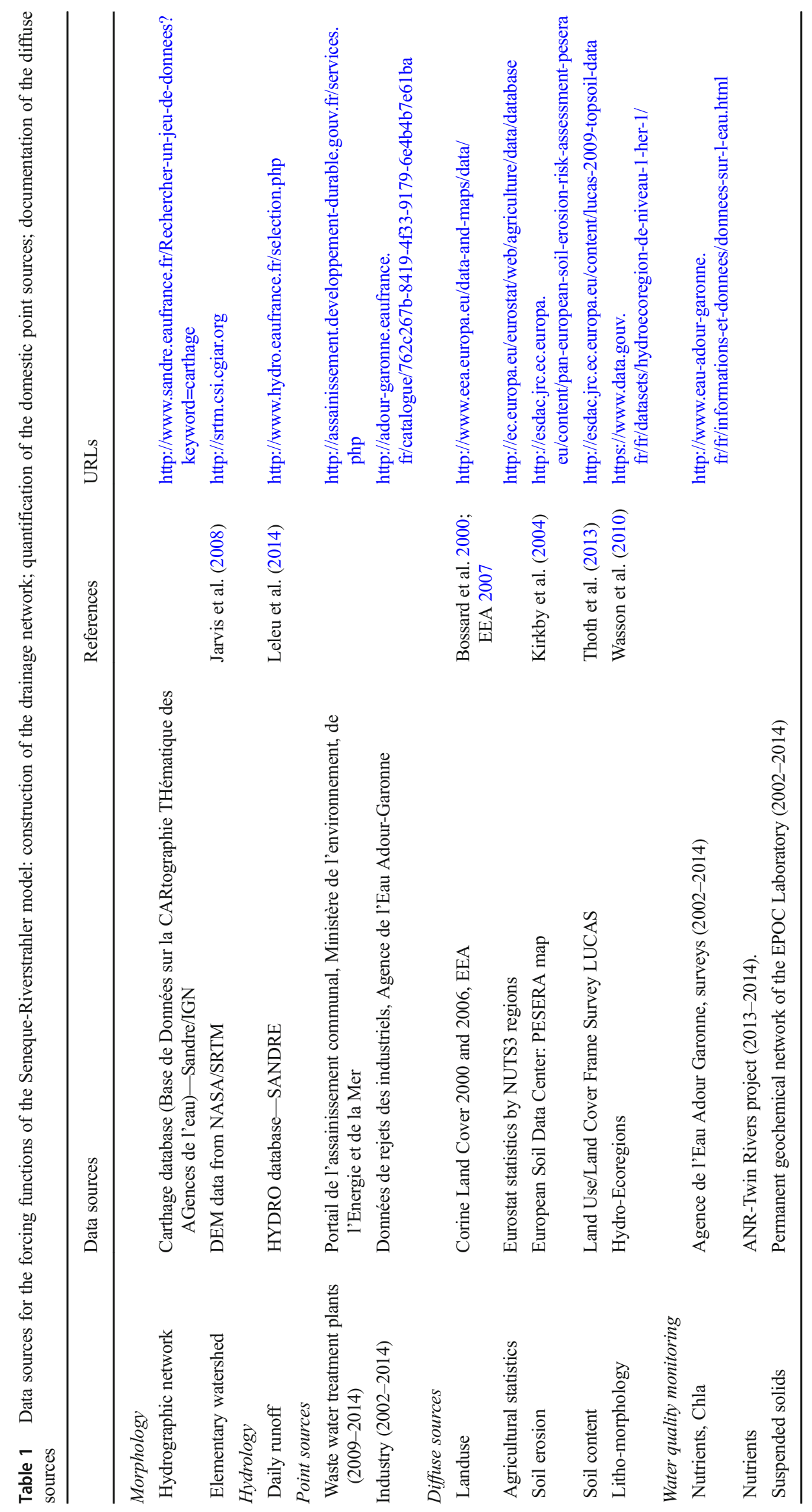



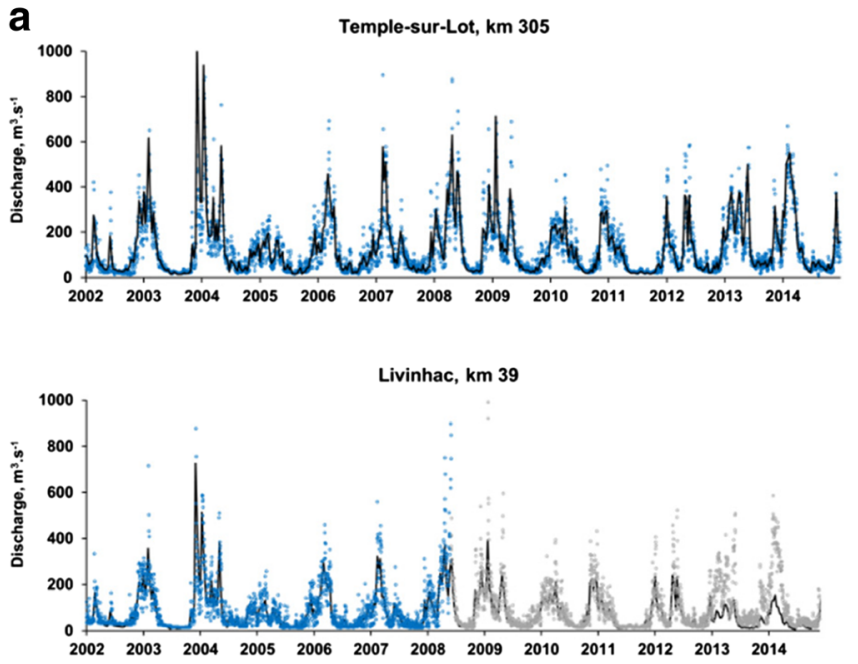

Fig. 2 a Averaged discharge (10 days) and comparison with the daily observed data (in blue) from 2002 to 2014 for the upstream station (Livinhac) and downstream station (Temple-sur-Lot) of the main branch of the Lot. Observations from 2008 to 2014 at Livinhac were reconstructed by subtracting the daily discharges of the major,

information (European Ecoregions: Wasson et al. 2010) using a simple dichotomy between crystalline and sedimentary rocks $\left(5 \mathrm{mg} \mathrm{Si} \mathrm{L}{ }^{-1}\right.$ for sedimentary rocks or recent alluviums and $3 \mathrm{mg} \mathrm{Si} \mathrm{L}{ }^{-1}$ for crystalline or metamorphic rocks, in accordance with the value provided by Meybeck 1986).

The approach used for nitrogen is more sophisticated, because the diffuse sources of this element are dependent on the structure of the agro-food system of the areas composing the watersheds. The GRAFS approach (Generalized Representation of Agro-Food Systems, Billen et al. 2014) was used to establish a comprehensive analysis of the agricultural EUROSTAT databases and to define the nitrogen surplus, which is then used to calculate the nitrogen leaching flux and concentrations (Anglade 2015).

\section{Validation of the model}

Kinetic physiological parameters involved in the model description have been determined through field or laboratory experiments under controlled conditions and are therefore a priori defined, so that no calibration procedure is required for running the model. The comparison between observations and simulations thus directly indicates the goodness of our knowledge of the forcing functions to the model (morphology, hydrology, point and diffuse inputs) as well as of the ecological processes taken into account. Using the same parameters, the Riverstrahler modeling approach has already been successfully applied to several river systems across the world (from the temperate Seine river (Billen et al. 2007) to the monsoon Red river (Le et al. 2014), from small streams (Garnier et al. 2014) to large rivers (Garnier et al. 2002), from pristine (Sferratore et al. 2008) to strongly human-impacted rivers (Billen et al. 2005; Thieu et al. 2009)).
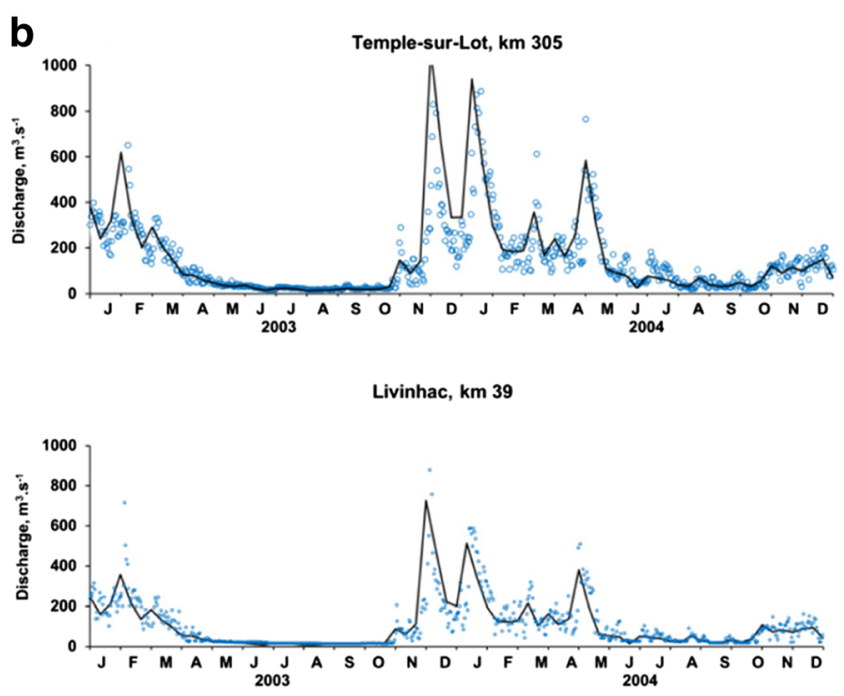

immediately downstream tributary, the Célé ( $\mathrm{km} \mathrm{116),} \mathrm{from} \mathrm{the} \mathrm{closest}$ Lot downstream station ( $\mathrm{km} \mathrm{143)}$ (in gray). b Seasonal variations of calculated and observed discharge for 2003 to 2004 for the upstream station and downstream station of the main branch of the Lot

Water quality data were gathered from the Adour-Garonne Water Agency surveys (1970-2014) and from the ANR-Twin Rivers project (2013-2014) and were used for interpreting long-term trends of water quality and for validating the model. Whereas water quality (nitrate, ammonium, phosphates and chlorophyll a) data from the water agency are available at intervals ranging from monthly to every 2 months, additional monthly data from the Twin Rivers project were included in the datasets (the same variables plus dissolved silica). Longterm (2002-2014) monitoring of daily suspended solid (SS) concentrations from the permanent geochemical network of the Laboratory EPOC (Coynel et al. 2007; Gil-Diaz et al. 2018) was also used.

We chose the Temple-sur-Lot and Livinhac stations to validate the hydrology (Livinhac, $\mathrm{km} \mathrm{39}$, downstream of the confluence of the upstream Lot and Truyère rivers and Temple-sur-Lot at km 305, Fig. 2). Regarding the validation of water quality, the Temple-sur-Lot station at the outlet of the Lot drainage network was selected.

Ammonium was measured in filtered water (GF/F 0.7- $\mu \mathrm{m}$ porosity) with the indophenol blue method according to Slavyck and McIsaac (1972). Nitrate was also measured in filtered water, after cadmium reduction into nitrite, and nitrite was measured with the sulfanilamide method according to Jones (1984). Dissolved ortho-phosphates in water were analyzed after GF/F filtration ( $0.7 \mu \mathrm{m}$ porosity) using the bluemolybdate colorimetric method (Eberlein and Kattner 1987). Dissolved silica (DSi) was determined by spectrophotometry and analyzed from water samples filtered through Whatman $\mathrm{GF} / \mathrm{F}$ filters and stored at $4{ }^{\circ} \mathrm{C}$ (Rodier 1984). Values of suspended solids (SS) were determined as the weight of material retained on a Whatman GF/F membrane per volume unit after drying the filter for $12 \mathrm{~h}$ at $50{ }^{\circ} \mathrm{C}$. Chlorophyll a and 
Table 2 Evaluation of the Seneque-Riverstrahler performances for the Lot river. The goodness of fit of the simulations with respect to the observed concentration values at the downstream station Temple has been evaluated for the major variables of water quality by calculating the root mean square error, normalized to the range of the observed data (NRMSE), according to the formula (NRMSE $=100 \times \mathrm{SQR}(1 / \mathrm{n}$ $\left.\Sigma_{\mathrm{t}}\left(\mathrm{Obs}_{\mathrm{i}}-\mathrm{Sim}_{\mathrm{i}}\right)^{2}\right) /\left(\mathrm{MAX}(\mathrm{Obsi})-\mathrm{MIN}\left(\mathrm{Obs}_{\mathrm{i}}\right)\right)$ where $n$ is the number of observations $\mathrm{Obs}_{\mathrm{i}}$ ). The NRMSE represents a percentage of variation whereas the bias is the slope of the regression line the slope of the regression line between simulated and observed values

\begin{tabular}{lccl}
\hline Variables & Nb of observations & \% NRMSE & Bias (dimless) \\
\hline Discharge & 4743 & 3 & 0.99 \\
Nitrate & 90 & 24 & 0.88 \\
Ammonium & 87 & 18 & 0.35 \\
Total P & 65 & 23 & 0.59 \\
o-phosphate & 88 & 17 & 0.18 \\
Chlorophyll a & 88 & 37 & 0.65 \\
Suspended matter & 4818 & 4 & 1.2 \\
\hline
\end{tabular}

phaeopigment concentrations were determined according to Lorenzen (1967).

RMSE normalized to the range of the observations (NRMSE, i.e., a percentage of variation) and bias (the slope of the regression line between simulated and observed values) was used as indexes of the goodness of fit of the model simulations.

\section{Results}

\section{Interannual variations of water flow and quality}

\section{Water flow}

As shown in Fig. 2a, the 10-day time resolution of our hydrological calculations did not significantly degrade the variations of the discharge data observed, with the exception of some very high transient peaks which were not closely reproduced at either station (Temple-sur-Lot and Livinhac). The average discharge at the outlet was $127 \mathrm{~m}^{3} \mathrm{~s}^{-1}$ with extreme values of $10.8 \mathrm{~m}^{3} \mathrm{~s}^{-1}$ (August 13, 2014) and $2506 \mathrm{~m}^{3} \mathrm{~s}^{-1}$ (December 5, 2003, a 50-year return flood discharge; Coynel et al. 2007). Focusing on the seasonal scale, summer and winter averaged 68 and $187 \mathrm{~m}^{3} \mathrm{~s}^{-1}$, respectively, for the whole period (Fig. 2b). For certain years (depending on oceanic and/or Mediterranean floods, or snowmelt), a second peak can be observed in April, shortening the low-discharge period. NRMSE and bias for discharge at the two stations over the period 2002-2014 both showed a good agreement between simulations and observations (Table 2).
Water quality As a whole, the simulations of major elements involved in phytoplankton development and eutrophication (nutrients, suspended solids) used for defining the quality of water masses show reasonable agreement with the observations. Although the temporality does not always fully fit with the measured values, the general levels and the amplitude of variation of the values are correctly reproduced (Fig. 3). Regarding modeling performances, for the bias, the model underestimated $\mathrm{P}_{-} \mathrm{PO}_{4}$ the most, but this might be due in part to the rather high detection limit of the analysis $(0.011 \mathrm{mg} \mathrm{P}$ $\mathrm{L}^{-1}$ ). Underestimation is less pronounced for ammonium, followed by TP and chlorophyll (Table 2). A good simulated level of the values is found for nitrate and suspended matter (as for discharge above). Whereas NRMSE is less than 25\% for all the variables, except for chlorophyll a, it is particularly low (i.e., high goodness) for discharge and suspended matter when the number of validation data is high (Table 2).

The nitrate concentrations observed were seasonally variable with slightly higher values in winter (mean, $1.6 \pm$ $0.4 \mathrm{mgN} \mathrm{L}^{-1}$ ) than in summer (mean, $0.9 \pm 0.5 \mathrm{mg} \mathrm{N} \mathrm{L}^{-1}$ ). Values of ammonium $\left(\mathrm{NH}_{4}\right)$ and phosphates $\left(\mathrm{PO}_{4}\right)$, indicators of point sources less diluted by low flow, were also higher in summer. Total phosphorus (TP) values equaled $0.07 \pm$ $0.04 \mathrm{mg} \mathrm{TP} \mathrm{L}^{-1}$ both in summer and winter (Table 3).

Suspended solids were $17.2 \pm 43.7 \mathrm{mg} \mathrm{SS} \mathrm{L}^{-1}$ in winter, higher than in summer $\left(12.6 \pm 16.7 \mathrm{mg} \mathrm{SS} \mathrm{L}^{-1}\right)$, and showed a high standard deviation, due to transient peaks related to upstream erosion and in-stream or reservoir sediment resuspension (Maneux et al. 2001) (Fig. 3b).

As expected from biological activity, chlorophyll (phytoplankton) concentrations were lower in winter than in

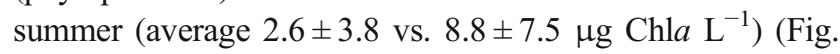
3a). Oxygen concentrations followed the saturation higher in winter than in summer (Table 3).

\section{Nutrient flux and ratios}

Once the interannual variability of water quality has been validated, the model can be used to calculate the average annual fluxes from the simulations (Fig. 4) by summing the various dominant forms of nitrogen, phosphorus, and silica represented in the model. TP and total nitrogen (TN) fluxes were calculated from the sum of the fluxes of inorganic dissolved forms $\left(\mathrm{PO}_{4}\right.$ and $\left.\mathrm{NO}_{3}, \mathrm{NH}_{4}\right)$ and the nitrogen and phosphorus included in the organic matter compartments. By adding DSi and biogenic silica (BSi), total silica (TSi) fluxes can be obtained. These fluxes varied within the range of 3.5$10.7 \mathrm{kt} \mathrm{N}$ year $^{-1}$ for $\mathrm{NO}_{3}$ and 3.7-12.8 kt N year ${ }^{-1}$ for TN, nitrate fluxes accounting for a high proportion $(85 \%)$ in TN. TP ranged between 0.11 and $0.60 \mathrm{kt} \mathrm{P} \mathrm{year}^{-1}$ with ophosphate flux accounting for a low fraction (11.5\%, with values from 0.034 to $0.061 \mathrm{kt} \mathrm{P}$ year $^{-1}$ for phosphates). TSi fluxes varied from 13.4 to $34.5 \mathrm{kt} \mathrm{TSi} \mathrm{year}^{-1}$, with mostly DSi 

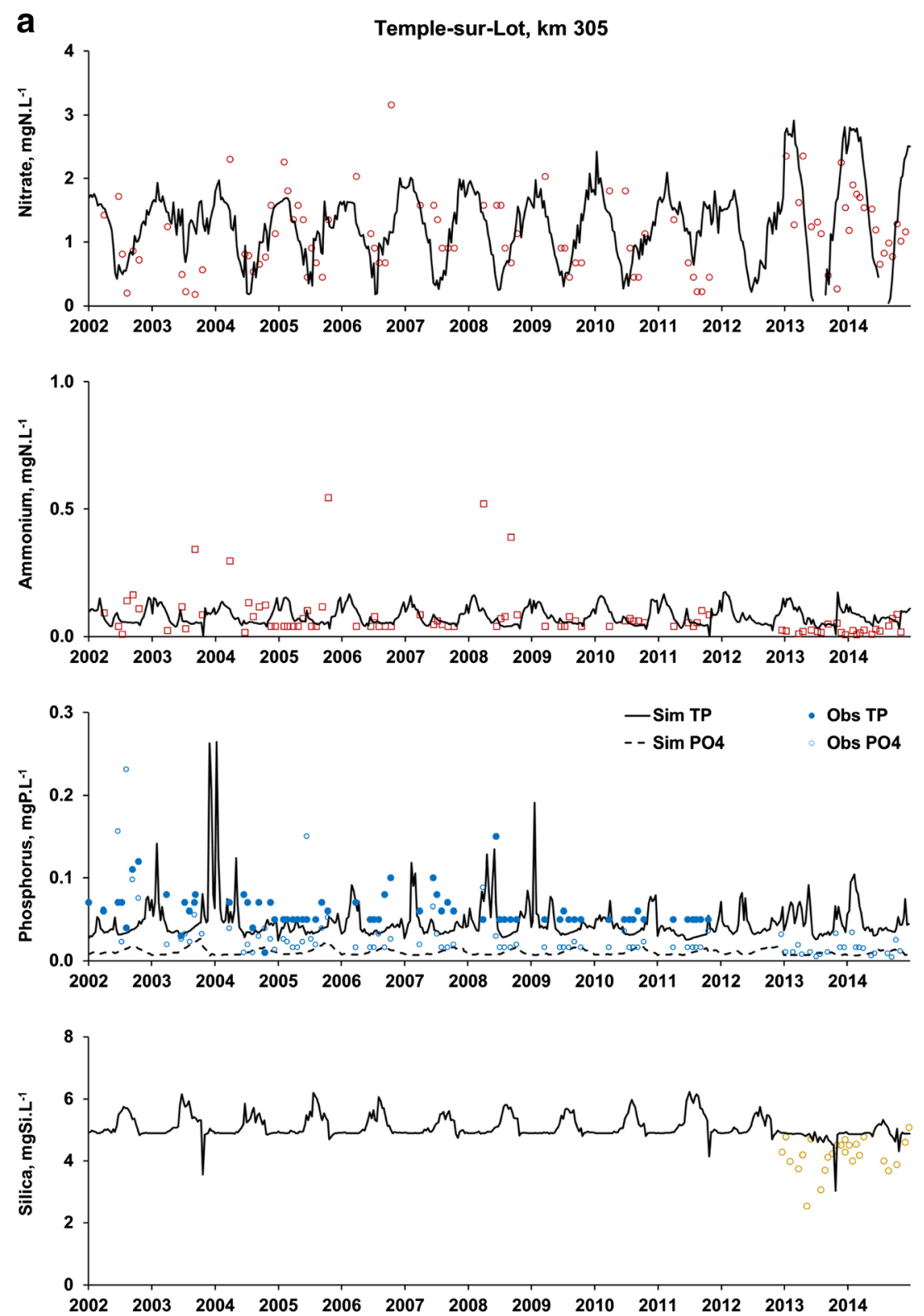

Fig. 3 Simulation by the Seneque-Riverstrahler model of interannual variations of the water quality variables and comparison with the observed data from 2002 to 2014 at the downstream Temple-sur-Lot

(90\%). Interannual variations of these fluxes varied along with average discharge, with 2003, 2008, and 2013 being the wettest years.

In addition to their absolute values, the ratios between $\mathrm{N}, \mathrm{P}$, and Si fluxes matter in terms of potential eutrophication. In particular, excess $\mathrm{N}$ or $\mathrm{P}$ fluxes with respect to $\mathrm{Si}$ can lead to unbalanced algal growth, favoring non-diatoms, often undesirable species, like toxic dinoflagellates or cyanobacteria. We calculated the N- and P-ICEP, indicators of potential eutrophication of nutrient fluxes (Billen and Garnier 2007; Garnier et al. 2010) (Fig. 5). ICEP is based on the C/N/P/Si ratios of 106:16:1:42 (Redfield et al. 1963; Conley et al. 1989). ICEP represents the excess (positive value) or deficit (negative station. a Dissolved nutrients (nitrate, ammonium, total phosphorus $[\mathrm{TP}]$ and phosphates $\left[\mathrm{PO}_{4}\right]$, dissolved silica [silica]). b Total suspended solids and biomass phytoplankton expressed in chlorophyll a

value) of either $\mathrm{N}$ or $\mathrm{P}$ over silica, a non-anthropogenic nutrient issued from rock weathering and essential for diatom growth. Positive P- and N-ICEP values mean that diatoms are Si-limited with regard to phosphorus and nitrogen, promoting the growth of non-siliceous, potentially toxic algae. Positive N-ICEP, i.e., with $N$ replenishment, has been suggested to indicate a risk of toxin production by several algal taxa (Gobler et al. 2007), but no clear results have been obtained yet (Pineda-Mendoza et al. 2016). The results show that in the Lot river, P-ICEP values were all negative (i.e., silica was in excess relative to phosphorus) averaging $-5.9 \mathrm{~kg} \mathrm{C}$ $\mathrm{km}^{-2}$ day $^{-1}$ (from -8.7 to $-2.8 \mathrm{~kg} \mathrm{C} \mathrm{km}^{-2}$ day ${ }^{-1}$ ), while $\mathrm{N}$ ICEP was positive (i.e., nitrogen in excess relative to silica) 

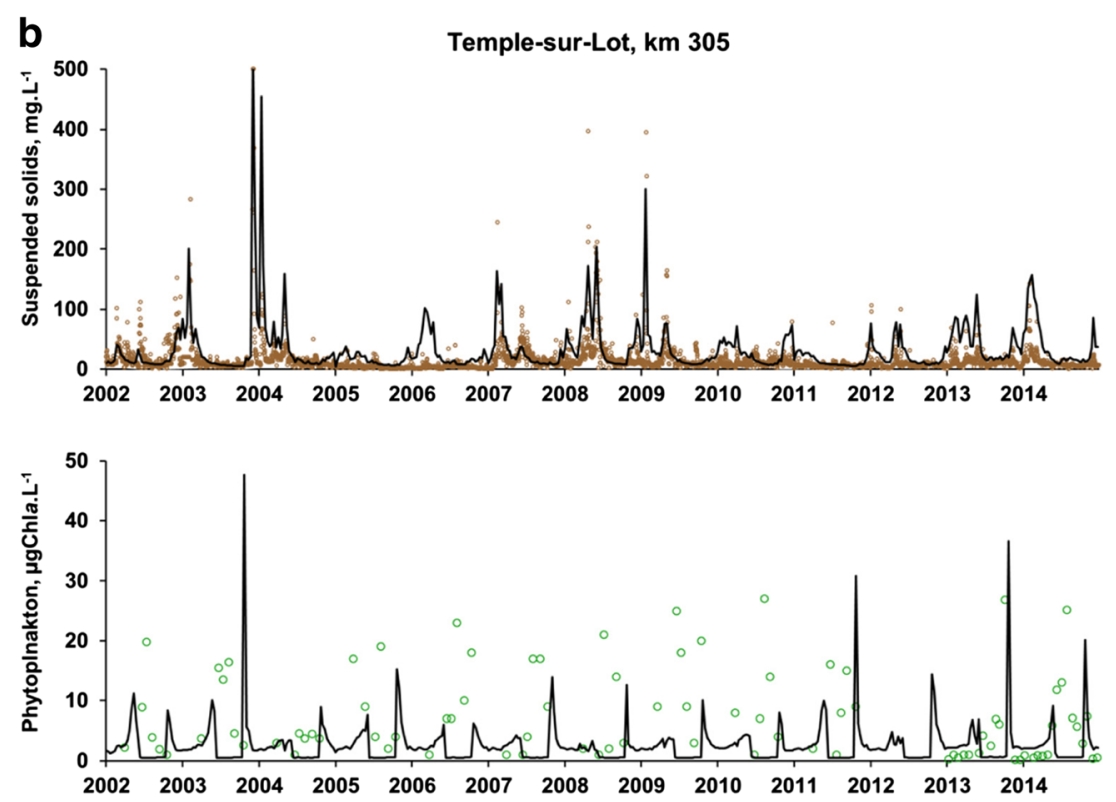

Fig. 3 continued.

averaging $3.8 \mathrm{~kg} \mathrm{C} \mathrm{km}^{-2}$ day $^{-1}$ (from 1.5 to $9.8 \mathrm{~kg} \mathrm{C}$ $\mathrm{km}^{-2}$ day $^{-1}$ ), with higher values for the last 2 years under study (7.1 and $9.8 \mathrm{~kg} \mathrm{C} \mathrm{km}^{-2}$ day $^{-1}$ in 2013 and 2014 , respectively).

\section{Long-term trends in nutrient concentrations}

The water quality data used to validate the model simulations at the Temple and Livinhac stations, at $\mathrm{km} 305$ and $\mathrm{km} \mathrm{39,}$ respectively, along the main branch of the Lot river, can be placed in a more comprehensive set of available data starting in the early 1970s (Fig. 6). The success of the wastewater purification policy implemented since the end of the 1970s was evidenced by the clear decrease in ammonium (from the 1990s on) and phosphate (after 2000) concentrations, in spite of the increase of the overall collected population of the watershed estimated at 232,000 inh. eq. in 1970 (Décamps 1978) and 530,000 in 2014.
In contrast, nitrate concentration regularly increased over the same period by approximately a factor of two. For avoiding eutrophication risks (Grizzetti et al. 2011) and protecting biodiversity of vegetal (James et al. 2005) and animal (Camargo et al. 2005) communities, nitrate values in surface water should remain in a range of $1.5-2 \mathrm{mg} \mathrm{N}^{-1}$. This threshold is occasionally exceeded in the lower part of the basin in the recent years (Figs. 3 and 6).

Although fewer data are available, the silica concentration did not show any significant trend during the last few years of the reconstruction period (1970-2015), which is expected because it is mainly caused by rock weathering.

\section{Wastewater treatment and agricultural scenarios}

Regarding nutrients and eutrophication, the Lot river does not show evidence of severe ecological dysfunctioning. However, as suggested by the increased nitrate concentrations, increasing intensive agriculture could become detrimental for the Lot

Table 3 Values of water quality variables: average and standard deviation (SD) for summer (May-October), winter periods (November-April), and all years from 2002 to 2014 (from 6 to 12 values per year, daily values for suspended solids, SS). NO3 nitrate, NH4 ammonium, TP total phosphorus, PO4 phosphates, $O X Y$ oxygen, CHLA chlorophyll a, SS suspended solids

\begin{tabular}{|c|c|c|c|c|c|c|c|c|}
\hline \multicolumn{2}{|c|}{ Observations } & \multirow{2}{*}{$\begin{array}{l}\begin{array}{l}\mathrm{NO} 3 \\
\mathrm{mg} \mathrm{N} \mathrm{L}^{-1}\end{array} \\
0.9\end{array}$} & \multirow{2}{*}{$\begin{array}{l}\begin{array}{l}\mathrm{NH} 4 \\
\mathrm{mg} \mathrm{N} \mathrm{L}^{-1}\end{array} \\
0.08\end{array}$} & \multirow{2}{*}{$\begin{array}{l}\mathrm{TP} \\
\mathrm{mg} \mathrm{P} \mathrm{L}^{-1} \\
0.07\end{array}$} & \multirow{2}{*}{$\begin{array}{l}\begin{array}{l}\mathrm{PO} 4 \\
\mathrm{mg} \mathrm{P} \mathrm{L}\end{array} \\
0.05\end{array}$} & \multirow{2}{*}{$\frac{\begin{array}{l}\mathrm{OXY} \\
\mathrm{mg} \mathrm{O} 2 \mathrm{~L}^{-1}\end{array}}{8.4}$} & \multirow{2}{*}{$\begin{array}{l}\begin{array}{l}\text { CHLA } \\
\mu \mathrm{g} \mathrm{Chla} \mathrm{L}\end{array} \\
8.6\end{array}$} & \multirow{2}{*}{$\frac{\begin{array}{l}\mathrm{SS} \\
\mathrm{mg} \mathrm{L}^{-1}\end{array}}{12.6}$} \\
\hline Summer & Average & & & & & & & \\
\hline & $S D$ & 0.5 & 0.08 & 0.04 & 0.10 & 1.5 & 7.5 & 16.7 \\
\hline \multirow[t]{2}{*}{ Winter } & Average & 1.6 & 0.06 & 0.07 & 0.02 & 11.2 & 2.6 & 17.2 \\
\hline & $S D$ & 0.4 & 0.10 & 0.04 & 0.02 & 1.4 & 3.8 & 43.7 \\
\hline \multirow[t]{2}{*}{ Year } & Average & 1.1 & 0.08 & 0.07 & 0.04 & 9.2 & 7.1 & 14.9 \\
\hline & $S D$ & 0.6 & 0.09 & 0.04 & 0.08 & 2.0 & 7.2 & 33.6 \\
\hline
\end{tabular}


Fig. 4 Yearly averaged fluxes, simulated by the Seneque-

Riverstrahler model for water discharge, total nitrogen (TN) and nitrate $\left(\mathrm{N}-\mathrm{NO}_{3}\right)$, total phosphorus (TP) and phosphates $\left(\mathrm{P}-\mathrm{PO}_{4}\right)$, and total silica (TSi)
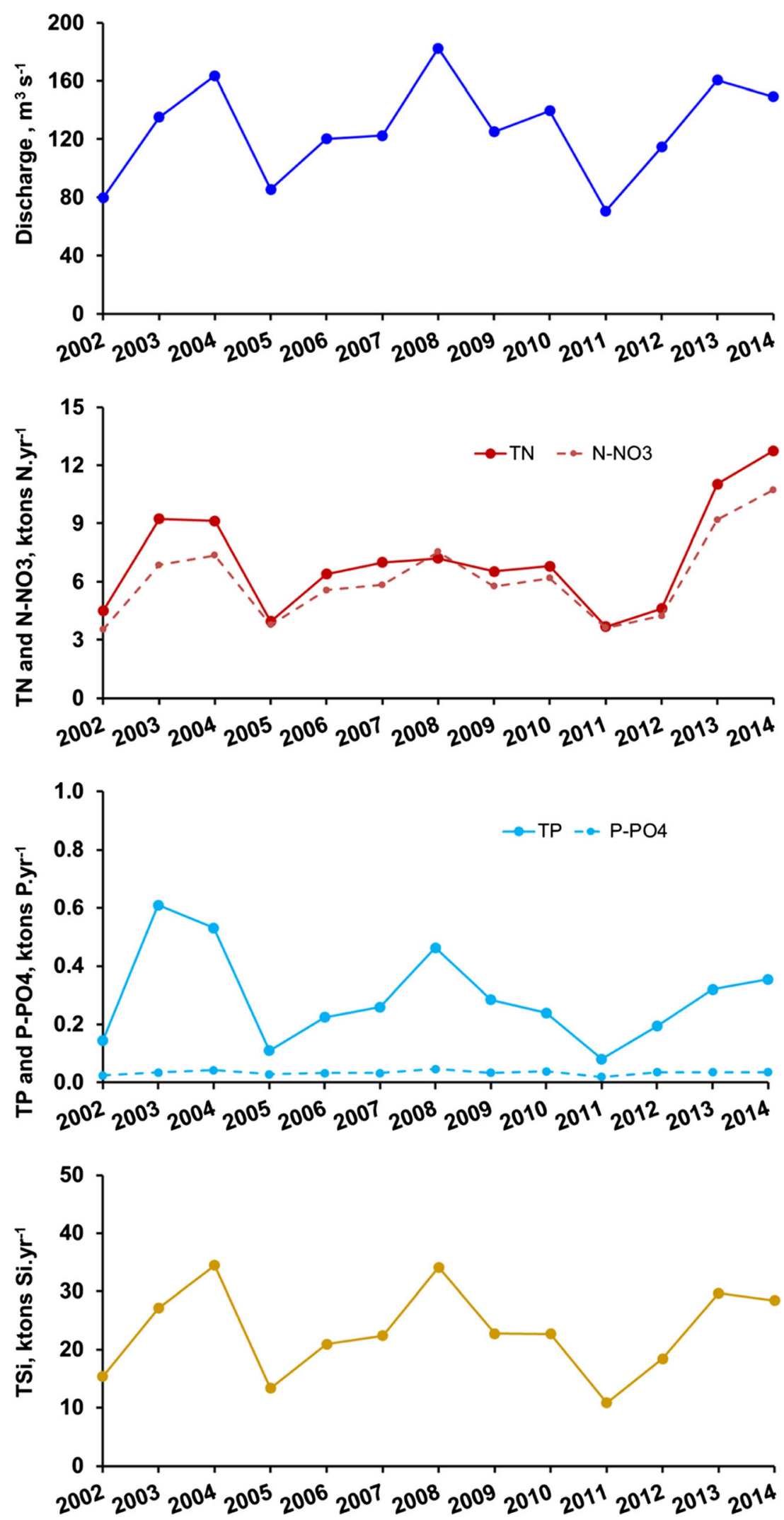

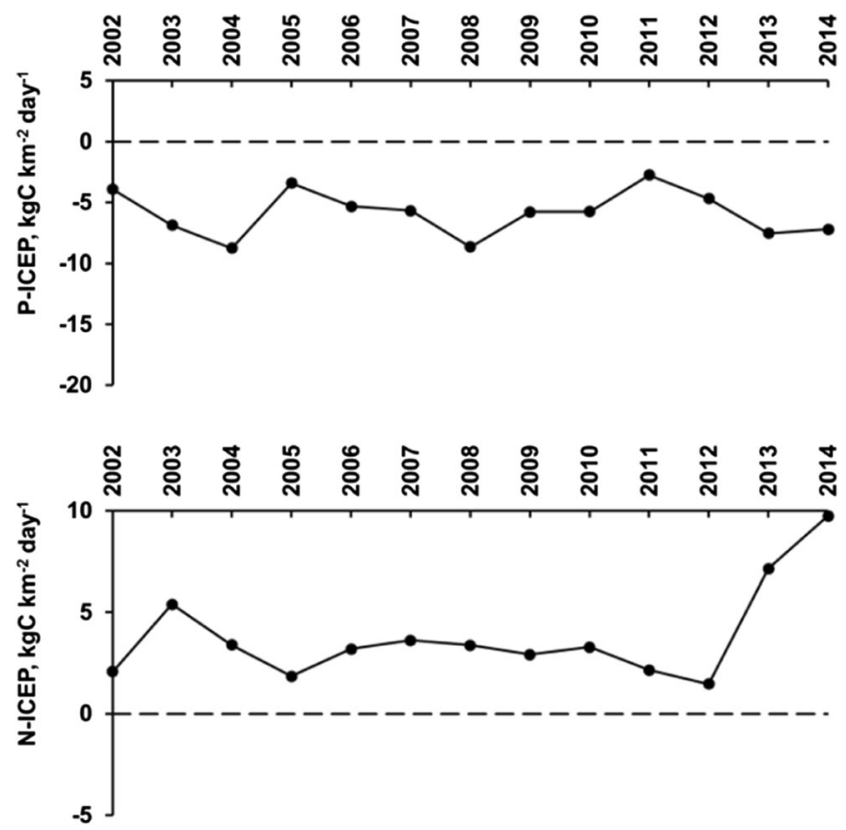

Fig. 5 Yearly average of ICEP indicators (P-ICEP and N-ICEP), calculated from yearly average TP, TN, and TSi fluxes
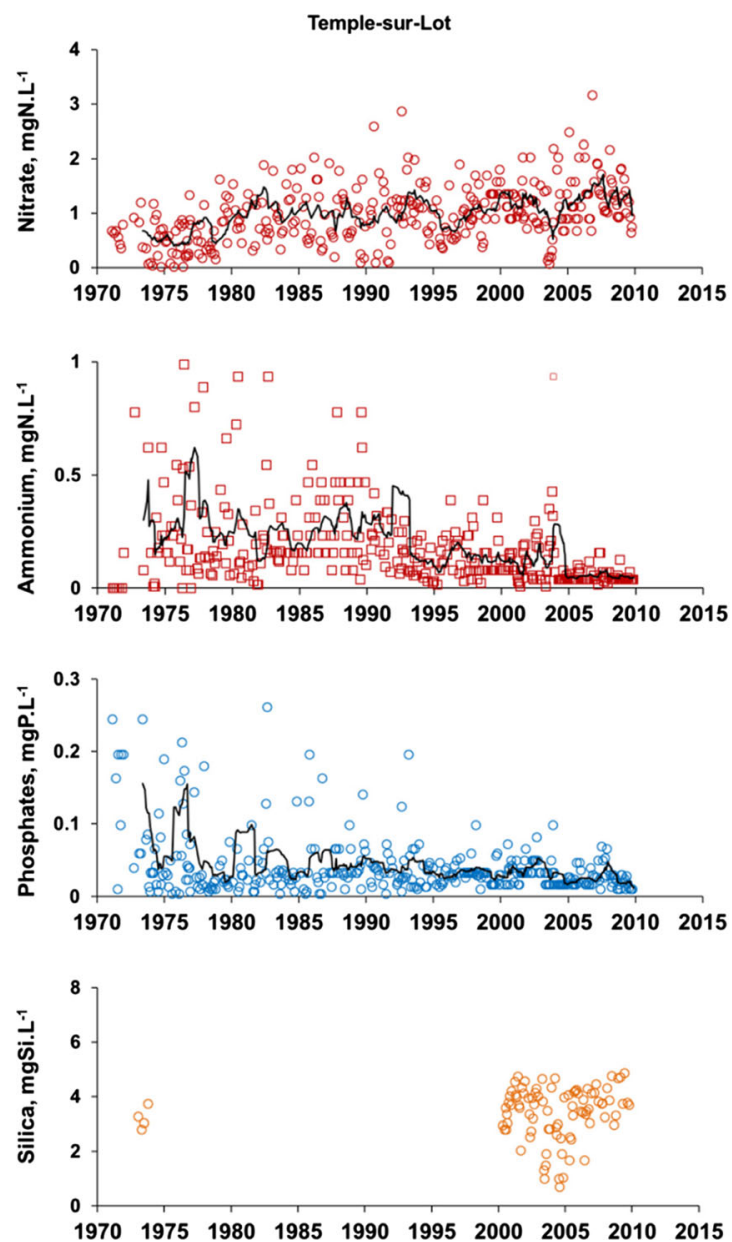

surface and groundwater quality, as for many other river systems in France and Europe.

Therefore, we explored three scenarios for representing possible futures of human activity in the Lot watershed. In addition to the simple compliance of the EU directive for wastewater treatment plants (i.e., phosphorus and nitrogen treatment, called the Urban Wastewater Directive, UWWD), we tested two contrasted agricultural scenarios. The first, here called good agricultural practices (GAP), assumes the same current conventional rotations, with full application of the current regulations (balanced fertilization following the agronomical recommendation with respect to current yield objectives and catch crop introduction before spring crops; Justes et al. 2012). The second involves a radical change in the present agro-food system, with generalization of organic farming based on long and diversified rotations (no use of mineral fertilizers), reconnection of livestock and crop farming following the specification for organic cattle breeding and the reduction of animal products in the human diet (the "Organic local demitarian scenario", OrgLocDem) (Billen
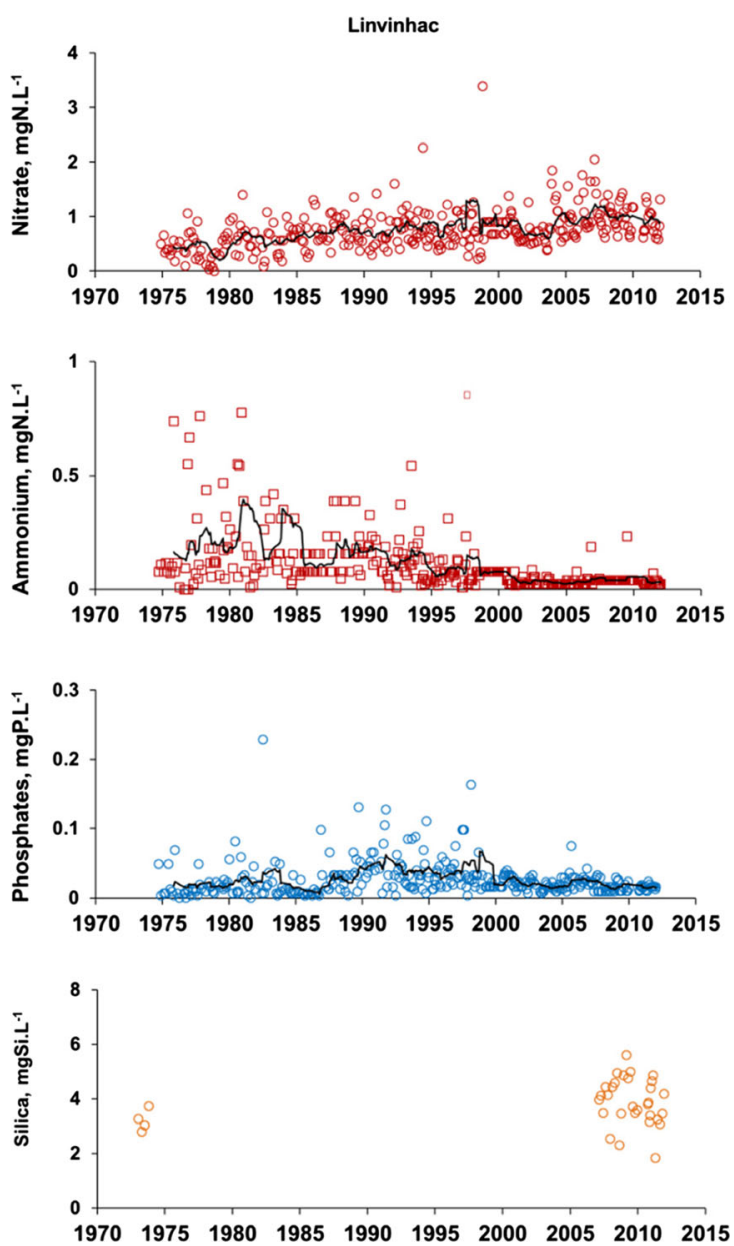

Fig. 6 Long-term variations of observed nitrate, ammonium, phosphates, and dissolved silica concentrations at two stations along the main branch of the Lot river. The solid line is the floating average (12-month increment) over the period covered by the data 
et al. 2016; Garnier et al. 2016). Both agricultural scenarios include the fulfillment of the UWWD prescriptions.

These scenarios were tested based on the situation established for the year 2014, a recent year with average annual hydrology $\left(149 \mathrm{~m}^{3} \mathrm{~s}^{-1}\right)$ close to the average calculated for the 13 years $\left(126 \mathrm{~m}^{3} \mathrm{~s}^{-1}\right)$ taken into account in the study and used here as the reference simulation.

As expected, silica fluxes did not change much for all scenarios. The UWWD scenario only slightly decreased phosphorus flux, which results from the fact that most wastewater treatment plants are already treating phosphorus in compliance with the EU directive. Regarding the agricultural scenarios, no further decrease in phosphorus fluxes was observed. Regarding nitrogen, although a $10 \%$ decrease of the flux was obtained for the GAP scenario, the OrgLocDem scenario led to a $40 \%$ reduction compared to the reference scenario (Fig. 7).

Two additional scenarios were run. The "pristine" scenario assumed no human activity in the watershed, which was considered entirely covered by forest. This scenario thus provided a baseline corresponding to the natural background of nutrient concentrations. In the "WWTP-LT" scenario, we explored the effect of a lower level of WWTP treatment: only standard activated sludge treatment was considered for cities above 2000 inh. eq., while smaller towns were considered to discharge their wastewater without any treatment (Fig. 7). Silica fluxes were slightly higher in the pristine scenario, because of lower in-stream consumption by diatoms. Regarding phosphorus, the pristine scenario showed a $24 \%$ lower flux compared to the reference situation. The WWTP-LT scenario, which simulated the level of wastewater treatment of the 1980-1990s, led to a $25 \%$ increase in phosphorus fluxes. Regarding nitrogen fluxes, the results for WWTP-LT scenario were close to the reference scenario, showing again that nitrogen originated predominantly from agricultural (Fig. 7). It is remarkable that scenarios such as the GAP and OrgLocDem, which only affected the rather limited agricultural area of the basin (6\% arable land, but $47 \%$ grassland), had a disproportionate effect on nitrate concentration and fluxes.

\section{Discussion}

\section{Strength and weakness of the approach}

The major strength of our study was to update, since the first works in the 1970s, the analysis of the biogeochemical functioning of the Lot river, in the new context of water quality directives with a comprehensive modeling approach.

The modeling approach applied here has required documenting the constraints that drive the biogeochemical behavior of river system at the scale of the whole basin (morphology and hydrology, diffuse sources from land use and point sources from all wastewater treatment plants). Data for the validation of the model had also to be gathered. The Riverstrahler model revealed to be a good tool for synthesizing all data available regarding nutrients and eutrophication.

A limitation to the study was data availability. For example, we used the same WWTP census data from 2002 to 2009, whereas we obtained data for each year from 2010 to 2014 . Changes in the location of the field measurement stations also required making various assumptions to take advantage of a maximum of existing data (see e.g., the reconstruction discharge values for Livinhac at the upstream Lot branch). Water quality data remained however scarce, except for suspended solids.

Also, in this study, we did not take into account the modeling of reservoirs as is generally done for other Riverstrahler model implementations (Garnier et al. 2000; Billen et al. 2007; Le et al. 2014). Taking into account the objective of the study, i.e., nutrient imbalance and eutrophication in the main branch of the Lot river, we therefore consider our approach valid once the discharge values, after separation of surface and base flows, are correctly simulated (see Fig. 2). Moreover, the modeling approach makes it possible to adequately simulate suspended solids, which can be trapped in the reservoirs (Vörösmarty et al. 2003; Dang et al. 2010; Quinton et al. 2010; Le et al. 2014). Although considering reservoirs in the drainage network continuum would help address new scientific questions, this would imply gathering many data
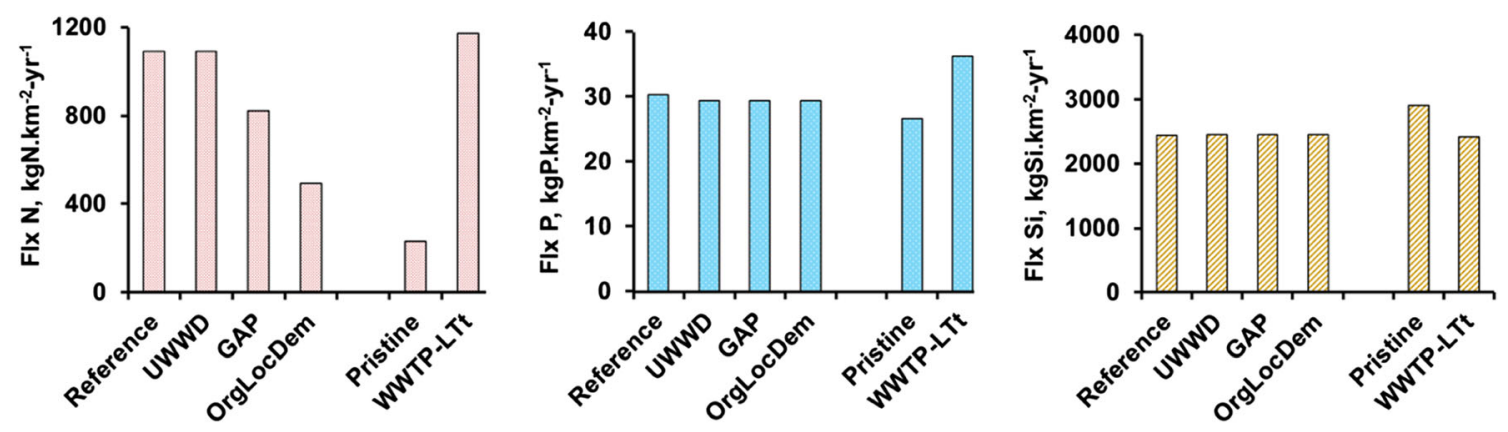

Fig. 7 Specific fluxes, simulated by the Seneque-Riverstrahler model of TN, TP, and TSi for the reference in 2014, compared with five scenarios: UWWD, improved wastewater treatment; GAP, good agricultural practices; OrgLocDem, generalized organic farming, reconnected to local needs, with a lower animal protein diet); Pristine: no anthropogenic perturbation; WWTP-LTt: poor wastewater treatment 
(reservoir morphology, discharge upstream and downstream, water quality data in the reservoirs) that are not available, either because they do not exist or because they are confidential.

\section{Nutrient concentrations and ecological status of the Lot river}

Ammonium concentrations at the Lot outlet plateaued at less than $0.1 \mathrm{mg} \mathrm{N}-\mathrm{NH}_{4} \mathrm{~L}^{-1}$ and the simulations agreed reasonably with most of the observations, except for a few outsider values at $0.3-0.5 \mathrm{mg} \mathrm{N}-\mathrm{NH}_{4} \mathrm{~L}^{-1}$ that were not well simulated, probably corresponding to occasional dysfunction of wastewater treatment plants (WWTPs). These values are rather low (about $0.05 \mathrm{mg} \mathrm{N}-\mathrm{NH}_{4} \mathrm{~L}^{-1}$, and similar to the Garonne riverLanoux 2013 - or to the Loire river-Gorse et al. 2010; Minaudo et al. 2015) with population density of 50 inh. $\mathrm{km}^{-2}$. For comparison with a fourfold higher population density, the ammonium level in the Seine river still averaged $0.7 \mathrm{~m} \mathrm{~N}^{-1}$ downstream Paris conurbation (Aissa-Grouz et al. 2015)

The model closely reproduced the large amplitude of nitrate variations attributable to denitrification in the riparian zones, as already observed in the Garonne river (Pinay et al., 2000; Sánchez-Pérez et al. 2003; Bernard-Jannin et al. 2017), rather than to benthic denitrification sediments (Thouvenot et al. 2007, 2009). This pattern of nitrate elimination in the riparian zones and flood plains is well documented in literature (Hill 1996; Pinay et al. 1993; Pinay et al. 2000; Billen and Garnier 2000; Vidon et al. 2010).

The simulation of phosphates was well within the average of the scatter, although some high values, especially at the beginning of the chronicle, were not reproduced by the model. Similar to ammonium, these high values might stem from WWTP dysfunction. Also, from 2007 to 2012, it seemed that the method used had a detection limit at $0.05 \mathrm{mg} \mathrm{P}^{-} \mathrm{PO}_{4} \mathrm{~L}^{-1}$, whereas lower values may have occurred. Such an acceptable simulation would show that $\mathrm{PO}_{4}$ adsorption-desorption processes, newly reparametrized in the model (Aissa-Grouz et al. 2016), were correctly taken into account. Compared with the very few values observed, the silica simulation represented the accurate level, although the decrease in concentration, corresponding to diatom uptake, is sometimes underestimated by the model.

The available long-term series of data (Fig. 6) showed a significant gradual decrease in ammonium and phosphate concentrations all along for the 1971-2010 period as already observed by Capblancq and Tourenq (1978). Regarding nitrate, a regular increase has been observed since the 1970s, in spite of the rather low contribution of arable land to the total land use of the watershed. However, nitrate concentrations in the Lot river remain relatively low compared to rivers with a high proportion of arable land and intensive agriculture, such as many other rivers in Europe (Bourraoui and Grizzetti 2011).

The negative values in P-ICEP indicate that diatoms are not Si-limited with regard to phosphorus, usually the limiting factor in continental water. The positive N-ICEP value, together with a N/P ratio averaging 28 , well above the value of 7 corresponding to the Redfield et al. (1963) ratio, could favor non-diatom development and possibly harmful algae (e.g., toxic Cyanobacteria or other non-grazed algal colonies, Diaz and Rosenberg 2008; Justic et al. 1995), especially if the phosphorus level increases (from WWTP point sources or diffuse soil erosion). These ICEP results followed downstream those found for the Garonne river of 6 and $-1 \mathrm{~kg} \mathrm{C} \mathrm{km}^{-2}$ day $^{-1}$ for N- and P-ICEP, respectively, for the 2001-2005 period (Romero et al. 2013).

\section{Future scenarios for the lot river: agriculture is the major lever of improvement}

Clearly, the lack of a noticeable difference in terms of nutrient fluxes between the reference situation and the scenario assuming perfect compliance with the urban effluent directive shows that wastewater treatment policy has already met its goal, and that no further improvement can be expected from point source management, both in terms of nitrogen and phosphorus reduction. This does not mean, however, that the level of wastewater treatment could be lowered. Indeed, any relaxation in the domestic effluent treatment (as shown by the low treatment scenario UWWT-LTt), with a strong development of tourism activity for example, could enhance algal development, especially because tourism activity reaches its maximum in summer when the water level is low. The Lot river, with $75 \mathrm{~km}$ of navigable river in the downstream section, is attractive for boating, and the Lot Valley is famous for its medieval cities (Conques, Figeac, Saint-Flour, Saint-Cirq Lapopie, Cahors) and its local gastronomy. Many hotels and campsites are already established along the river and this influx of tourists could increase here. Undersizing of WWTPs combined with a dry summer could expose the Lot river to cyanobacteria development and toxin production, as was observed in the nearby Tarn river (Bertrand et al. 2004) and several other rivers in the south of France as mentioned in the "Introduction" section.

Major improvement in water quality is expected from measures taken in the agricultural sector to reduce $\mathrm{N}$ losses. Even though only $6 \%$ of the watershed area is covered by arable land mostly situated in the basin of the Lot's major branch (Livihac-Temple-sur-Lot), compliance with good agricultural practices could reduce $\mathrm{N}$ fluxes by $20 \%$. This GAP scenario would lead to a $40 \%$ reduction of N-ICEP $(2.3 \mathrm{~kg}$ $\mathrm{C} \mathrm{km}^{-2} \mathrm{day}^{-1}$ ), for which nitrogen would still indicate a risk for eutrophication, together with phosphorus. More structural changes in agriculture would reduce nitrogen fluxes by $45 \%$ 
and N-ICEP even more $\left(-0.5 \mathrm{~kg} \mathrm{C} \mathrm{km}^{-2}\right.$ day $^{-1}$, i.e., nitrogen no more in excess to silica), showing that agriculture development can continue once sustainable practices are adopted.

\section{Conclusion}

Despite that wastewater management has considerably reduced the eutrophication potential regarding phosphorus (in absolute levels as well as in terms of ratio regarding silica, cf. negative P-ICEP), a threat still exists due to nitrogen which has regularly increased in the main stem of the Lot and is now in large excess compared to silica and phosphorus. Instead of forming large algal biomass, and hence oxygen deficit through organic matter degradation, the main concern of eutrophication seems to be a development of rather small biomass of toxic cyanobacteria, leading to domestic animal kills. Because tourism is an important economic activity of this region, including recreative water activities (boating, fishing, bathing), public authorities want preventing any health problem. However, agriculture (vineyards, market gardening, maize cropping for duck keeping) is also a major economic issue. Our scenarios show that a change in agriculture production would allow conciliating both tourism and agriculture.

Acknowledgements The TWINRIVERS Programme AAP Blanc Inter II SIMI 5-6 2011 project was funded by the National Agency for Research (ANR-11-IS56-0003) and was coordinated by Alexandra Coynel. Georges Vachaud is greatly acknowledged for his kind and relevant advice during the project. We would like to sincerely thank our scientific colleagues for the pioneering work carried out in the 1970s on rivers providing enthusiasm to the next generations of researchers.

\section{References}

Aissa Grouz A, Garnier J, Billen G, Mercier B, Martinez A (2015) The response of river nitrification to changes in wastewater treatment (the case of the lower Seine River downstream from Paris). Ann Limnol - Int J Lim 51(4):351-364. https://doi.org/10.1051/limn/ 2015031

Aissa Grouz N, Garnier J, Billen G (2016) Long trend reduction of phosphorus wastewater loading in the seine: determination of phosphorus speciation and sorption for modeling algal growth. Environ Sci Pollut Res. https://doi.org/10.1007/s11356-016-7555-7

Anglade A (2015) Agriculture biologique, qualité de l'eau et gouvernance. Ph-D Univ. Paris 6 (UPMC), ED "Géosciences et Ressources Naturelles". 295 pp.

Arini A, Baudrimont M, Feurtet-Mazel A, Coynel A, Blanc G, Coste M, Delmas F (2011) Comparison of periphytic biofilm and filterfeeding bivalve metal bioaccumulation $(\mathrm{Cd}$ and $\mathrm{Zn})$ to monitor hydrosystem restoration after industrial remediation: a year of biomonitoring. J Environ Monit 13(12):3386-3398. https://doi.org/10. 1039/c1em10581g

Audry S, Schafer J, Blanc G, Jouanneau JM (2004a) 50-year sedimentary record of heavy metal pollution $(\mathrm{Cd}, \mathrm{Zn}, \mathrm{Cu}, \mathrm{Pb})$ in the Lot river reservoirs (France). Environ Pollut 132(3):413-426. https://doi.org/ 10.1016/j.envpol.2004.05.025
Audry S, Schafer J, Blanc G, Jouanneau JM (2004b) 50-year sedimentary record of heavy metal pollution $(\mathrm{Cd}, \mathrm{Zn}, \mathrm{Cu}, \mathrm{Pb})$ in the Lot river reservoirs (France). Environ Pollut 132(3):413-426. https://doi.org/ 10.1016/j.envpol.2004.05.025

Audry S, Grosbois C, Bril H, Schafer J, Kierczak J, Blanc G (2010) Postdepositional redistribution of trace metals in reservoir sediments of a mining/smelting-impacted watershed (the Lot river, SW France). Appl Geochem 25:78-794

Bernard-Jannin L, Sun X, Teissier S, Sauvage S, Sánchez-Pérez JM (2017) Spatio-temporal analysis of factors controlling nitrate dynamics and potential denitrification hot spots and hot moments in groundwater of an alluvial floodplain. Ecol Eng 103:372-384 https://doi.org/10.1016/j.ecoleng.2015.12.031

Bertrand F, Dunand A, Fosse J, Fradin N, Liger D, Keck G (2004) Les intoxinations par les cyanobactéries. Le Point Vétérinaire 250:4650

Billen G, Garnier J, Hanset P (1994) Modelling phytoplankton development in whole drainage networks: the RIVERSTRAHLER model applied to the Seine river system. Hydrobiologia 289:119-137

Billen G, Garnier J (2000) Nitrogen transfers through the Seine drainage network: a budget based on the application of the Riverstrahler model. Hydrobiologia 410:139-150

Billen G, Garnier J, Rousseau V (2005) Nutrient fluxes and water quality in the drainage network of the Scheldt basin over the last 50 years. Hydrobiologia 540(1-3):47-67. https://doi.org/10.1007/s10750004-7103-1

Billen G, Garnier J (2007) River basin nutrient delivery to the coastal sea: assessing its potential to sustain new production of non siliceous algae. Mar Chem 106:148-160. https://doi.org/10.1016/j.marchem. 2006.12.017

Billen G, Garnier J, Némery J, Sebilo M, Sferratore A, Barles S, Benoit P, Benoit M (2007) Nutrient transfers through the Seine river continuum: mechanisms and long term trends. Sci Total Environ 375(1-3): 80-97. https://doi.org/10.1016/j.scitotenv.2006.12.005

Billen G, Lasseletta L, Garnier J (2014) A biogeochemical view of the global agro-food system: nitrogen flows associated with protein production, consumption and trade. Global Food Security 3(3-4): 209-219. https://doi.org/10.1016/j.gfs.2014.08.003i

Billen G, Le Noë J, Lassaletta L, Thieu V, Anglade J, Petit L, Garnier J (2016) Et si la France passait au régime «Bio, Local et Demitarien » ? Un scénario radical d'autonomie protéique et azotée de l'agriculture et de l'élevage, et de sobriété alimentaire. Le DEMETER 2017, 23ème Edition, Economie et stratégie agricoles, p 389-406. Club DEMETER, Paris ISSN/1166-2115

Blanc G, Lapaquellerie Y, Maillet N, Anschutz P (1999) A cadmium budget for the Lot-Garonne fluvial system (France). Hydrobiologia 410:331-341.

Bossard M, Feranec J, Otahel J (2000) Corine land cover technical guide-addendum 2000, technical report no 40. EEA, Copenhagen http://www.eea.eu.int

Bouraoui F, Grizzetti B (2011) Long term change of nutrient concentrations of rivers discharging in European seas. Sci Total Environ 409(2011):4899-4916. https://doi.org/10.1016/j.scitotenv.2011.08. 015

Camargo JA, Alonso A, Salamanca A (2005) Nitrate toxicity to aquatic animals: a review with new data for freshwater invertebrates. Chemosphere 58(9):1255-1267. https://doi.org/10.1016/j. chemosphere.2004.10.044

Capblancq J, Dauta A (1978) Phytoplancton et production primaire de la rivière Lot. Annls Limnol 14(1-2):85-112. https://doi.org/10.1051/ limn/1978006

Capblancq J, Tourenq J-N (1978) Hydrochimie de la rivière Lot. Annls Limnol. 14(1-2):25-37. https://doi.org/10.1051/limn/1978003

Capblancq J, Dauta A, Caussade B, Décamps H (1982) Variations journalières de la production phytoplanctonique en rivière : 
modélisation d'un bief du Lot. Annls Limnol. 18(2):101-132. https://doi.org/10.1051/limn/1982017

Conley DJ, Kilham SS, Theriot EC (1989) Differences in silica content between marine and freshwater diatoms. Limnol Oceanogr 34(1): 205-213. https://doi.org/10.4319/lo.1989.34.1.0205

Coynel A, Schafer J, Dabrin A, Girardot N, Blanc G (2007) Groundwater contributions to metal transport in a small river affected by mining and smelting waste. Water Res 41(15):3420-3428. https://doi.org/ 10.1016/j.watres.2007.04.019

Coynel A, Blanc G, Marache A, Schafer J, Dabrin A, Maneux E, Bossy C, Masson M, Lavaux G (2009) Assessment of metal contamination in a small mining-affected watershed - high resolution monitoring coupled with spatial analysis by GIS. J Environ Monit 11(5):962976. https://doi.org/10.1039/b818671e

Coynel A, Garnier J, Némery J, Blanchet Ph , Delmas F (2016) Sustainable and integrated management on watersheds facing industrial pollution and urbanization. A comparative study between Lot river (France) and Danshui River (Taiwan). Projet ANR-11-IS56-0003 TWINRIVERS Programme AAP Blanc Inter II SIMI 5-6 2011. 24pp

Dang TH, Coynel A, Orange D, Blanc G, Etcheber H, Le LA (2010) Long-term monitoring (1960-2008) of the river-sediment transport in the Red River watershed (Vietnam): temporal variability and dam-reservoir impact. Sci Total Environ 408(20):4654-4664. https://doi.org/10.1016/j.scitotenv.2010.07.007

Davis AS, Hill JD, Chase CA, Johanns AM, Liebman M (2012) Increasing cropping system diversity balances productivity, profitability and environmental health. PLoS One 7, e47149. doi: 10.1371/ journal.pone.0047149, DOI: https://doi.org/10.1371/ journal.pone.0047149

Décamps H (1978) Qualité des eaux et développement de la Vallée du Lot. Annls Limnol 14(1-2):163-179. https://doi.org/10.1051/limn/ 1978018

Diaz RJ, Rosenberg R (2008) Spreading dead zones and consequences for marine ecosystems. Science 321(5891):926-929, ISSN:00368075. https://doi.org/10.1126/science. 1156401

Eberlein K, Kattner G (1987) Automatic method for the determination of ortho-phosphate and total dissolved phosphorus in the marine environment. Fresenius' Z Anal Chem 326(4):354-357. https://doi.org/ 10.1007/BF00469784

Eckhardt K (2008) A comparison of baseflow indices, which were calculated with seven different baseflow separation methods. J Hydrol 352(1-2):168-173. https://doi.org/10.1016/j.jhydrol.2008.01.005

EEA, European Environment Agency (2007) CLC2006 technical guidelines. Technical Report No. 17/2007. European Environment Agency, Luxembourg

Garnier J, Billen G, Coste M (1995) Seasonnal succession of diatoms and Chlorophyceae in the drainage network of the river Seine: observations and modelling. Limnol Oceanogr 40:750-765

Garnier J, Billen G, Sanchez N, Leporcq B (2000) Ecological functioning of a large reservoir in the upstream basin of the river Seine (Marne reservoir, France). Regulated River 16:51-71

Garnier J, Billen G, Hannon E, Fonbonne S, Videnina Y, Soulie M (2002) Modeling transfer and retention of nutrients in the drainage network of the Danube River. Estuar Coast Shelf Sci 54(3):285-308. https:// doi.org/10.1006/ecss.2000.0648

Garnier J, Beusen A, Thieu V, Billen G, Bouwman L (2010) N:P:Si nutrient export ratios and ecological consequences in coastal seas evaluated by the ICEP approach. Special issue "Past and Future Trends in Nutrient Export from Global Watersheds and Impacts on Water Quality and Eutrophication", Global Biogeochem. Cycles, 24, GB0A05, doi:https://doi.org/10.1029/2009GB003583

Garnier J, Billen G, Vilain G, Benoit M, Passy P, Tallec G, Tournebize J, Anglade J, Billy C, Mercier B, Ansart P, Sebilo M, Kao C (2014) Curative vs. preventive management of nitrogen transfers in rural areas: lessons from the case of the Orgeval watershed (Seine River basin, France). J Environ Manag 144:125-134. https://doi.org/10. 1016/j.jenvman.2014.04.030

Garnier J, Anglade J, Benoit M, Billen G, Puech T, Ramarson A, Passy P, Silvestre M, Lassaletta L, Trommenschlager J-M, Schott C, Tallec G (2016) Reconnecting crop and cattle farming to reduce nitrogen losses in river water of an intensive agricultural catchment (Seine basin, France). Environ Sci Policy 63:76-90. https://doi.org/10. 1016/j.envsci.2016.04.019

Gil-Diaz T, Schäfer J, Coynel A, Bossy C, Dutruch L, Blanc G (2018) Antimony in the Lot-Garonne River system: a thirteen-year record of solid/liquid partitioning and fluxes. http://www.publish.csiro.au/ EN/justaccepted/EN17188

Gobler CJ, Davis TW, Coyne KJ, Boyer GL (2007) Interactive influences of nutrient loading, zooplankton grazing, and microcystin synthetase gene expression on cyanobacterial bloom dynamics in a eutrophic New York lake. Harmful Algae 6(1):119-133. https://doi.org/10. 1016/j.hal.2006.08.003

Gorse L, Etcheber H , Coynel A, Anschutz P, Grosbois C, Maillet G, Savoye N, Abril G, Moatar M, Sottolichio A, Maneux E (2010) Analyse multi-proxies des eaux du bassin de la Loire intérieure et estuarienne. 23ème Réunion des Sciences de la Terre, 25-29 oct. 2010, Bordeaux, France

Grizzetti B, Bouraoui F, Billen G, van Grinsven H, Cardoso AC, Thieu V, Garnier J, Curtis C, Howarth R, Jones P (2011) Chapter 17: reactive nitrogen as a threat to European water quality, 379-404. Part IVmanaging nitrogen in relation to key societal treats. In: Assessment EN (ed) Sutton et al._Cambridge University Press, London, 612pp

Hill AR (1996) Nitrate removal in stream riparian zones. J Environ Qual 25:743-755

James C, Fisher J, Russel V, Collings S, Moss B (2005) Nitrate availability and hydrophyte species richness in shallow lakes. Freshw Biol 50(6): 1049-1063. https://doi.org/10.1111/j.1365-2427.2005.01375.x

Jarvis A, Reuter HI, Nelson A, Guevara E (2008) Hole-filled SRTM for the globe Version 4, available from the CGIAR-CSI SRTM 90m Database (http://srtm.csi.cgiar.org)

Jones MN (1984) Nitrate reduction by shaking with cadmium, alternative to cadmium columns. Water Res 18:643-646

Justes E, Beaudoin N, Bertuzzi P, Charles R, Constantin J, Durr C, Hermon C, Joannon A, Le Bas C, Mary B, Mignolet C, Montfort F, Ruiz L, Sarthou J-P, Souchere V, Tournebize J, Savini I, Rechauchère O (2012) Réduire les fuites de nitrate au moyennde cultures intermédiaires: conséquences sur les bilans d'eau et d'azote, autres services écosystémiques. Expertise collective INRA, France, p 60

Justić D, Rabalais NN, Turner RE (1995) Stoichiometric nutrient balance and origin of coastal eutrophication. Mar Pollut Bull 30(1):41-46. https://doi.org/10.1016/0025-326X(94)00105-I

Kirkby MJ, Jones RJA, Irvine, B, Gobin A, Govers G, Cerdan O, Van Rompaey AJJ, Le Bissonnais Y, Daroussin J, King D, Montanarella L, Grimm M, Vieillefont V, Puigdefabregas J, Boer M, Kosmas C, Yassoglou N, Tsara M, Mantel S, Van Lynden GJ, Huting J (2004) Pan-European soil erosion risk assessment: the PESERA map Version 1 October 2003. Explanation of Special Publication Ispra 2004 No.73 (S.P.I.04.73), European Soil Bureau Research Report No.16, EUR 21176, Office for Official Publications of the European Communities, Luxembourg $18 \mathrm{pp}$.

Lapaquellerie Y, Jouanneau JM, Maillet N, Latouche C (1995) Cadmium pollution in sediments of the lot river (France). Estimate of the mass of cadmium. Environ Technol 16:1145-1154

Lanoux A (2013) Caractérisation et rôle respectif des apports organiques amont et locaux sur l'oxygénation des eaux de la Garonne estuarienne. $\mathrm{PhD}$ thesis of University Bordeaux 1 -. available on http://www.theses.fr/2013BOR14830

Le TPQ, Billen G, Garnier J (2014) Long-term evolution of the biogeochemical functioning of the Red River (Vietnam): past and present situations. REC 15(2):329-339. https://doi.org/10.1007/s10113014-0646-4 
Leleu I, Tonnelier I, Puechberty R, Gouin P, Viquendi I, Cobos L, Foray A, Baillon M, Ndima P-O (2014) La refonte du système d'information national pour la gestion et la mise à dispo- sition des données hydrométriques. La Houille Blanche (1):25-32. https://doi. org/10.1051/lhb/2014004

Lorenzen CJ (1967) Determination of chlorophyll and phaeopigments: spectrophotometric equations. Limnol Oceanogr 12(2):343-346. https://doi.org/10.4319/1o.1967.12.2.0343

Maneux E, Probst JL, Veyssy E, Etcheber H (2001) Assessment of dam trapping efficiency from water residence time: application to fluvial sediment transport in the Adour, Dordogne and Garonne river basins (France). Water Resour Res 37:801-811

Meybeck M (1986) Composition chimique des ruisseaux non polluées de France. Sci Géol Bull 39:3-77

Minaudo C, Meybeck M, Moatar F, Gassana N, Curie F (2015) Eutrophication mitigation in rivers: 30 years of trends in spatial and seasonal patterns of biogeochemistry of the Loire River (1980-2012). Biogeosciences 12(8):2549-2563. https://doi.org/10. 5194/bg-12-2549-2015

Morin S, Duong TT, Dabrin A, Coynel A, Herlory O, Baudrimont M, Delmas F, Durrieu G, Schafer J, Winterton P, Blanc G, Coste M (2008) Long term survey of heavy metal pollution, biofilm contamination and diatom community structure in the Riou-Mort watershed, south West France. Environ Pollut 151(3):532-542. https:// doi.org/10.1016/j.envpol.2007.04.023

Passy P, Gypens N, Billen G, Garnier J, Lancelot C, Thieu V, Rousseau V, Callens J (2013) A model reconstruction of riverine nutrient fluxes and eutrophication in the Belgian coastal zone since 1984. J Mar System 128:106-122. https://doi.org/10.1016/j.jmarsys.2013.05. 005

Pinay G, Roques L, Fabre A (1993) Spatial and temporal patterns of denitrification in a riparian Forest. J Appl Ecol 30(4):581-591. https://doi.org/10.2307/2404238

Pinay G, Black VJ, Planty-Tabacchi AM, Gumiero B, Decamps H (2000) Geomorphic control of denitrification in large river floodplain soils. Biogeochemistry 50(2):163-182. https://doi.org/10.1023/A: 1006317004639

Pineda-Mendoza RM, Zuniga G, Martınez-Jeronimo F (2016) Microcystin production in Microcystis aeruginosa: effect of type of strain, environmental factors, nutrient concentrations, and $\mathrm{N}: \mathrm{P}$ ratio on mcyA gene expression. Aquat Ecol 50(1):103-119. https://doi.org/10.1007/s10452-015-9559-7

Quinton JN, Govers G, Van Oost K, Bardgett RD (2010) The impact of agricultural soil erosion on biogeochemical cycling. Nat Geosci 3(5):311-314. https://doi.org/10.1038/ngeo838

Redfield AC, Ketchum BH, Richards FA (1963) The influence of organisms on the composition of sea-water. In: Hill MN (ed) The sea. John Wiley, New York, pp 12-37

Rodier J (1984) L'analyse de l'eau. 7e édition. DUNOD

Romero E, Garnier J, Lassaletta L, Billen G, Le Gendre R, Riou P, Cugier P (2013) Large-scale patterns of river inputs in SW Europe: seasonal and interannual variations and potential eutrophication effects at the coastal zone. Biogeochemistry 113(1-3):481-505. https://doi.org/ 10.1007/s10533-012-9778-0

Romero E, Le Gendre R, Garnier J, Billen G, Fisson C, Silvestre M, Ph R (2016) Long-term water quality in the lower Seine: lessons learned over 4 decades of monitoring. Environ Sci Policy 58:141-154. https://doi.org/10.1016/j.envsci.2016.01.016

Ruelland D, Billen G, Brunstein D, Garnier J (2007) SENEQUE 3: a GIS interface to the RIVERSTRAHLER model of the biogeochemical functioning of river systems. Sci Total Environ 375(1-3):257-273. https://doi.org/10.1016/j.scitotenv.2006.12.014

Sánchez-Pérez JM, Vervier P, Garabétian F, Sauvage S, Loubet M, Rols JL, Bariac T, Weng P (2003) Nitrogen dynamics in the shallow groundwater of ariparian wetland zone of the Garonne SW France: nitrate inputs, bacterialdensities, organic matter supply and denitrification measurements. HydrolEarth Syst Sci 7(1):97-107, https:// doi.org/10.5194/hess-7-97-2003

Sferratore A, Billen G, Garnier J, Humborg C, Rahm L (2008) Modelling nutrient fluxes from sub-arctic basins: comparison of pristine vs. dammed rivers. J Mar Syst 73(3-4):236-249. https://doi.org/10. 1016/j.jmarsys.2007.10.012

Shinn C, Dauba F, Grenouillet G, Guenard G, Lek S (2009) Temporal variation of heavy metal contamination in fish of the river lot in southern France. Ecotoxicol Environ Saf 72(7):1957-1965. https:// doi.org/10.1016/j.ecoenv.2009.06.007

Slavyck G, McIsaac JJ (1972) Comparison of two automated ammonium methods in a region of coastal upwelling. Deep-Sea Res 19:1-4

Strahler A (1957) Quantitative analysis of watershed geomorphology. Trans Am Geophys Union 38(6):913-920. https://doi.org/10.1029/ TR038i006p00913

Thieu V, Billen G, Garnier J (2009) Nutrient transfer in three contrasting NW European watersheds: the Seine, Somme, and Scheldt rivers. A comparative application of the Seneque/Riverstrahler model. Water Res 43(6):1740-1754. https://doi.org/10.1016/j.watres.2009.01.014

Thébaut J-M, Quotbi A (1999) A model of phytoplankton development in the Lot river (France). Simulation and scenarios Wat Res 33: 1065-1079

Thouvenot M, Billen G, Garnier J (2007) Modelling nutrient exchange at the sediment - water interface of river systems. J Hydrol 341(1-2): 55-78. https://doi.org/10.1016/j.jhydrol.2007.05.001

Thouvenot-Korppoo M, Billen G, Garnier J (2009) Modelling benthic denitrification processes over a whole drainage network. J Hydrol 379(3-4):239-250. https://doi.org/10.1016/j.jhydrol.2009.10.005

Toth G, Jones A, Montanarella L. (eds.) 2013. LUCAS topsoil survey. Methodology, data and results. JRC Technical Reports. Luxembourg. Publications Office of the European Union, EUR 26102, Scientific and Technical Research series. ISSN 1831-9424 (online); ISBN 978-92-79-32542-7; doi: https://doi.org/10.2788/ 97922

Tourenq J-N, Capblancq J, Casanova H (1978) Bassin versant et hydrologie de la rivière Lot. Annls Limnol 14(1-2):9-23. https:// doi.org/10.1051/limn/1978005

Ulén B, Bechmann M, Fölster J, Jarvie HP, Tunney H (2007) Agriculture as a phosphorus source for eutrophication in the north-west European countries, Norway, Sweden, United Kingdom and Ireland: a review. British Society of Soil Science, Soil Use Manag 23(Suppl. 1):5-15. https://doi.org/10.1111/j.1475-2743.2007. 00115.x

Vidon P, Craig A, Douglas B, Duval TP, Gurwick N, Inamdar S, Lowrance R, Okay J, Scott D, Sebestyen S (2010) Hot spots and hot moments in riparian zones: potential for improved water quality management. J Am Water Resour Assoc (JAWRA) 46(2):278-298. https://doi.org/ 10.1111/j.1752-1688.2010.00420.X

Volk M, Liersch S, Schmidt G (2009) Towards the implementation of the European water framework directive? Lessons learned from water quality simulations in an agricultural watershed. Land Use Policy 26:580e 588

Vörösmarty CJ, Meybeck M, Fekete B, Sharma K, Green P, Syvitski JPM (2003) Anthropogenic sediment retention: major global impact from registered river impoundments. Glob Planet Chang 39(1-2):169190. https://doi.org/10.1016/S0921-8181(03)00023-7

Wasson JG, Villeneuve B, Iital A, Murray- Bligh J, Dobiasova M, Bacikova $S$ et al (2010) Large-scale relationships between basin and riparian land cover and the ecological status of European rivers. Freshw Biol 55:1465-1482

WFD (Water Framework Directive) (2000). OJ L 327/1, 22.12, pp. 1-72

UWWTD (Urban wastewater treatment Directive) (1991) 91/271/CEE du Conseil, du 21mai 1991, relative au traitement des eaux urbaines résiduaires. JO L 135 du 30.5.1991, pp. 40-52 